\title{
Fallopian Metaplastic Papillary Tumour: An Atypical Transdifferentiation of the Tubal Epithelium?
}

\author{
Miguel Fdo. Salazar ${ }^{1,2}$ \\ Isaías Estrada Moscoso ${ }^{1}$ \\ Lorena Troncoso Vázquez ${ }^{1}$ \\ Nubia Leticia López García ${ }^{2}$ \\ Paola Andrea Escalante Abril ${ }^{2}$ \\ ${ }^{1}$ Anatomical Pathology Division, "Dr. Manuel Gea \\ González" General Hospital; "Pathology Unit, \\ Mexico General Hospital, Mexico City, Mexico \\ Received: August 3, 2014 \\ Revised: September 22, 2014 \\ Accepted: October 13, 2014

\section{Corresponding Author} \\ Miguel Fdo. Salazar, M.D. \\ División de Anatomía Patológica, Hospital General \\ "Dr. Manuel Gea González", Calzada de Tlalpan \\ 4800, Col. Sección XVI, Delegación Tlalpan, C.P. \\ 14080, D.F. México \\ Tel: +52-4000-3000 (ext. 3302) \\ E-mail: k7nigricans@hotmail.com
}

A metaplastic papillary tumor of the Fallopian tube is an extremely uncommon condition, with odd and confusing features that make it difficult to categorize as benign or borderline. Here, we summarize all the published cases to date and document the case of a 41-year-old woman diagnosed with this alteration after her last childbirth and ensuing tubal ligation. One of the tubes was bulky and filled with a caramel-like substance encircling a blurry spot. Light microscopy detailed a slender stalk covered by eosinophilic, columnar plump cells, showing atypical nuclei and focal budding. Mitotic figures were absent. The immunohistochemistry panel was positive for pan-cytokeratin, epithelial membrane antigen, cyclin D1, and hormone receptors. Additionally, a proliferation index of less than $5 \%$ was rated using Ki- 67 . The true nature of this tumor (reactive vs neoplastic) is uncertain. Nonetheless, its association with pregnancy suggests an adaptive change, likely similar to the atypical transdifferentiation proposed for Arias-Stella reaction.

Key Words: Metaplastic papillary tumour; Fallopian tubes; Arias-Stella reaction; Cell transdifferentiation
Metaplastic papillary tumors of the Fallopian tube represent an extremely unusual finding particularly related to pregnancy and with morphological features that make precise histopathological classification difficult. At present, nearly ten case reports are documented worldwide (Table 1$){ }^{1-7}$

\section{CASE REPORT}

The patient, a 41-year-old woman with a non-relevant past medical history, concluded her fourth pregnancy by cesarean delivery owing to macrosomic product (July 2013). Tubal ligation was performed on postoperative day one by the Kroener fimbriectomy method, which coursed uneventfully and without any remarkable findings. The specimens obtained were sent for routine histopathological assessment, and the patient was discharged after full recovery. To date she is healthy and without any complaints.

Both distal tubes and fimbriae were identified; the large tube was bulky with a nodular appearance $(3.5 \times 2 \times 1.3 \mathrm{~cm})$ (Fig. 1A). Transverse sections taken from this dilated duct revealed an overfilled lumen with a caramel-like substance surrounding an ill-defined peripheral spot, which, when seen under a magnifying glass, showed a fractal pattern similar to a snowflake (Fig. 1B). Histologically, this hazy frame was sketched by a slender stalk with progressively branching papillae lined by columnar non-ciliated cells with plump eosinophilic cytoplasm showing focal pseudostratification and budding (Fig. 1C, D). The nuclei of these cells were centrally located, enlarged, and rounded or oval. The nuclei displayed a variable appearance, either dense and hyperchromatic, or vesicular with a prominent nucleolus, and sometimes having coarse chromatin, membrane foldings, pseudoinclusions or grooves. Mitotic activity was not identified.

Despite the presence of luminal extracellular mucin, several subnuclear mucin-filled vacuoles were also identified, occasionally expanding into cyst-like structures (Fig. 2A). Periodic acidSchiff and Alcian blue stains highlighted the extracellular and 
Table 1. Metaplastic papillary tumor case list

\begin{tabular}{|c|c|c|c|c|c|c|}
\hline \multirow{2}{*}{$\begin{array}{l}\text { Case } \\
\text { No. }\end{array}$} & \multirow{2}{*}{ Year } & \multirow{2}{*}{$\begin{array}{l}\text { Author } \\
\text { (country) }\end{array}$} & \multicolumn{3}{|c|}{ Clinical data overview } & \multirow{2}{*}{ Histopathological finding } \\
\hline & & & Landscape & Evolution and treatment & Follow-up & \\
\hline 1 & 1978 & $\begin{array}{l}\text { Starr et al. } .^{2} \\
(\text { USA })\end{array}$ & 26-Year-old woman (G2P1) & $\begin{array}{l}\text { Normal delivery and imme- } \\
\text { diate postpartum tubal } \\
\text { ligation } \\
\text { Total abdominal hysterecto- } \\
\text { my and bilateral salpingo- } \\
\text { oophorectomy performed } \\
\text { due to report of malignancy }\end{array}$ & $\begin{array}{l}\text { Check-up every } 3 \text { months } \\
\text { during a non-specified } \\
\text { period } \\
\text { No anomalies reported }\end{array}$ & $\begin{array}{l}\text { Interpretation as grade } 1 \text { primary } \\
\text { adenocarcinoma of the Fallopian } \\
\text { tube }\end{array}$ \\
\hline $2-5$ & 1980 & $\begin{array}{l}\text { Saffos et al. }{ }^{1} \\
\text { (USA) }\end{array}$ & $\begin{array}{l}\text { Four women between } 27 \text { to } \\
33 \text { years of age (multiparous; } \\
\text { non-specified number of } \\
\text { pregnancies) } \\
\text { One patient had used oral } \\
\text { contraceptives several } \\
\text { years previously }\end{array}$ & $\begin{array}{l}\text { Normal delivery and tubal } \\
\text { ligation in every case } \\
\text { Two patients had total ab- } \\
\text { dominal hysterectomies } \\
\text { with bilateral salpingo-oo- } \\
\text { phorectomies because of } \\
\text { uncertainty about the ma- } \\
\text { lignancy of the lesions }\end{array}$ & $\begin{array}{l}\text { No evidence of disease in } \\
\text { three patients after differ- } \\
\text { ent times of evaluation } \\
\text { (1 year } 6 \text { months, } 2 \text { years } \\
\text { and } 6 \text { years postopera- } \\
\text { tively) } \\
\text { One of the cases was lost } \\
\text { during follow-up }\end{array}$ & $\begin{array}{l}\text { Original description of the tumour: } \\
\text { oncocytic and mucinous epithelia } \\
\text { Mucinous component (intracyto- } \\
\text { plasmic vacuoles) reactive for } \\
\text { mucicarmine stain } \\
\text { Only one mitosis noticed in one of } \\
\text { the cases }\end{array}$ \\
\hline 6 & 1988 & $\begin{array}{l}\text { Keeney and } \\
\text { Thrasher }{ }^{3} \\
\text { (USA) }\end{array}$ & $\begin{array}{l}\text { 27-Year-old Mexican woman } \\
\text { (G3P1A1) } \\
\text { Hypothyroidism requiring } \\
\text { L-tiroxine therapy }\end{array}$ & $\begin{array}{l}\text { Premature rupture of foetal } \\
\text { membranes with subse- } \\
\text { quent caesarean delivery } \\
\text { Simultaneous tubal ligation }\end{array}$ & $\begin{array}{l}\text { Without disease after } \\
4 \text { years of follow-up }\end{array}$ & $\begin{array}{l}\text { No gross abnormalities } \\
\text { Description of a luminal acidophilic } \\
\text { secretion mucicarmine-positive } \\
\text { Recognition of only one tripolar } \\
\text { mitosis } \\
\text { First ultrastructural description by } \\
\text { means of transmission electron } \\
\text { microscopy }\end{array}$ \\
\hline 7 & 1989 & $\begin{array}{l}\text { Bartnik et al. }{ }^{4} \\
\text { (USA) }\end{array}$ & $\begin{array}{l}\text { 23-Year-old woman (G3P2) } \\
\text { Respiratory and urinary tract } \\
\text { infections treated with ampi- } \\
\text { cillin during the second and } \\
\text { third trimesters }\end{array}$ & $\begin{array}{l}\text { Vaginal delivery and tubal } \\
\text { ligation (Pomeroy } \\
\text { technique) }\end{array}$ & $\begin{array}{l}\text { Postoperative recovery } \\
\text { and discharge }\end{array}$ & $\begin{array}{l}\text { Gross description of a pale-yellow } \\
\text { mucoid material (extracellular } \\
\text { mucin within the tubal lumen) } \\
\text { No mitotic activity } \\
\text { First description of the cell immuno- } \\
\text { phenotype: CK (+) and EMA (+) } \\
\text { Minimal chronic salpingitis observed } \\
\text { in both tubes }\end{array}$ \\
\hline 8 & 1999 & $\begin{array}{l}\text { Pang } \\
\text { (Taiwan) }\end{array}$ & $\begin{array}{l}\text { 52-Year-old non-pregnant } \\
\text { Taiwanese woman (G5P3A2) } \\
\text { Consumption of progesterone- } \\
\text { only oral contraceptives } \\
\text { when she was } 26 \text { years old } \\
\text { Complaint of lower abdominal } \\
\text { fullness } \\
\text { Bilateral hydrosalpinx by ultra- } \\
\text { sonography }\end{array}$ & $\begin{array}{l}\text { Laparoscopic resection } \\
\text { of both Fallopian tubes }\end{array}$ & Non-available information & $\begin{array}{l}\text { Tumour localized in the right salpinx } \\
\text { Intracellular mucin reactive for PAS, } \\
\text { alcian blue and mucicarmine } \\
\text { stains } \\
\text { Extracellular mucine present on the } \\
\text { surface of some papillae } \\
\text { Simultaneous finding of degenerat- } \\
\text { ed, partially calcified chorionic villi } \\
\text { in both Fallopian tubes (bilateral } \\
\text { ectopic pregnancies) }\end{array}$ \\
\hline 9 & 2003 & $\begin{array}{l}\text { Solomon } \\
\text { et al. }{ }^{6} \\
\text { (USA) }\end{array}$ & $\begin{array}{l}\text { 26-Year-old woman (G5P3A1) } \\
\text { Last pregnancy conceived } \\
\text { while using oral contracep- } \\
\text { tives } \\
\text { Unexplained serum FP eleva- } \\
\text { tion during the 15th week of } \\
\text { gestation }\end{array}$ & $\begin{array}{l}\text { Labor induction at } 39 \\
\text { weeks using oxytocin } \\
\text { Vaginal delivery and bilateral } \\
\text { tubal ligation via Pomeroy } \\
\text { procedure on postpartum } \\
\text { day } 1\end{array}$ & $\begin{array}{l}\text { No complaints after her } \\
\text { 6-week postpartum visit }\end{array}$ &  \\
\hline 10 & 2011 & $\begin{array}{l}\text { D'Adda et al. }{ }^{7} \\
\text { (Italy) }\end{array}$ & $\begin{array}{l}\text { 31-Year-old woman at her } \\
\text { 40th week of gestation }\end{array}$ & $\begin{array}{l}\text { Caesarean delivery due to } \\
\text { podalic version }\end{array}$ & Non-available information & $\begin{array}{l}\text { Microsatellital analysis of eight } \\
\text { chromosomal regions involved in } \\
\text { ovarian carcinogenesis: molecular } \\
\text { profile probably similar to a sub- } \\
\text { set of minimally altered low-grade } \\
\text { borderline serous tumours }\end{array}$ \\
\hline
\end{tabular}

CK, cytoketarin; EMA, epithelial membrane antigen; PAS, periodic acid-Schiff.

intracellular mucin, while the intracytoplasmic vacuoles were stained with Mayer's mucicarmine (Fig. 2B-D).

Immunoperoxidase stains demonstrated an intensely positive reaction for cytokeratin cocktail $\left(\mathrm{CK} \mathrm{AE}_{1} / \mathrm{AE}_{3}\right)$ in the membrane and cytoplasm (Fig. 3A) of cells, as well as for epithelial membrane antigen (EMA) with weak cytoplasmic expression and lu- 

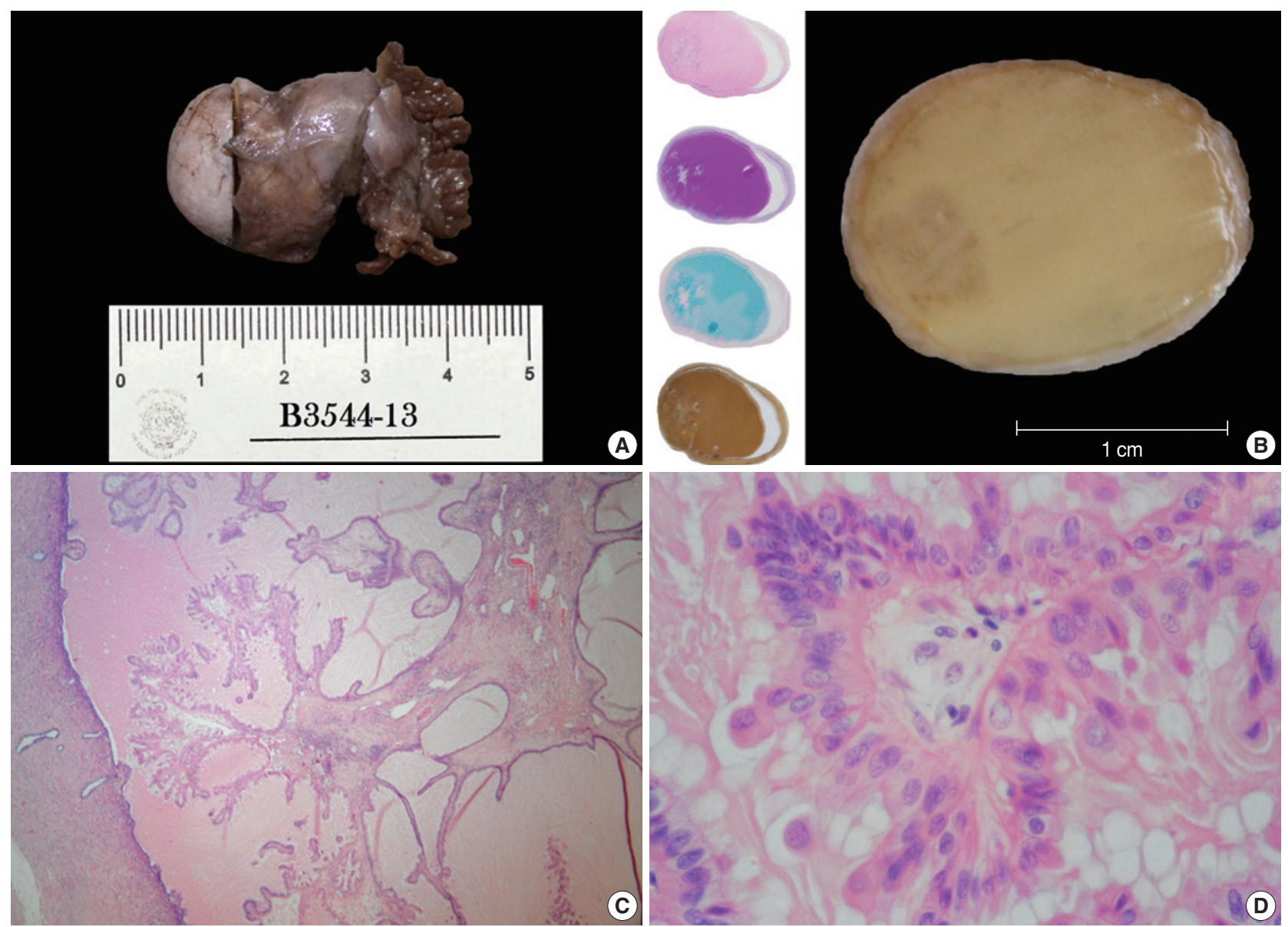

Fig. 1. Gross features/oxyphil metaplastic components. (A) Tubal ligation specimen. (B) Transverse cut surface. A crystallized syrup-like substance with a striking resemblance to a regional candy known as «acitrón» fills the lumen; there is also a left marginal blur with a snowflakelike appearance. The left column displays whole-mount sections stained with hematoxylin and eosin, periodic acid-Schiff, Alcian blue, and mucicarmine. (C) Panoramic photomicrograph showing a peninsular papillary framework in a lake of extracellular mucin. The stalk has a loose stroma and contains a small number of inflammatory cells (lymphocytes and neutrophils). (D) High magnification photomicrograph of the oncocytic epithelium. There is mild stratification and cell budding.

minal border reinforcement (Fig. 3B). Detection of progesterone receptors (PR) was markedly positive in $95 \%$ of cells, while estrogen receptors (ER) and androgen receptors were moderately and weakly positive in $70 \%$ and $10 \%$ of cells, respectively (Fig. 3C-E). The proliferation index labeled with Ki-67 was rated in approximately $3 \%$ of cells (Fig. 3F). Surprisingly, cyclin D1 staining was observed in nearly $90 \%$ of cells (Fig. 3G). No reaction was detected toward a variety of factors, including carcinoembryonic antigen (CEA), human chorionic gonadotropin, human epidermal growth factor receptor 2 (HER2/Neu), or B-cell lymphoma 2 protein (Bcl-2).

Accordingly, the proliferation was diagnosed as a metaplastic papillary tumor of the Fallopian tube, with a note to the clinician about the benign behavior of the alteration.

\section{DISCUSSION}

In the 1980s, a group led by Saffos and Scully described an unusual epithelial tumor incidentally discovered in four cases involving tubal ligation after delivery (early puerperium). ${ }^{1}$ The morphology detailed in their report describes a papillary stalk lined by atypical oxyphil columnar cells with pseudostratification, budding elements, and focal adenomatous changes involving intramucosal mucin-filled vacuoles, nonetheless, lacking invasion or mitotic activity. According to these features, the team coined a description of this singular pathological entity as a metaplastic papillary tumor of the Fallopian tube. Furthermore, they noticed a striking similarity with serous borderline ovarian tumors, as well as a close association with pregnancy. This led the team to speculate about either a neoplastic nature of the tumor 

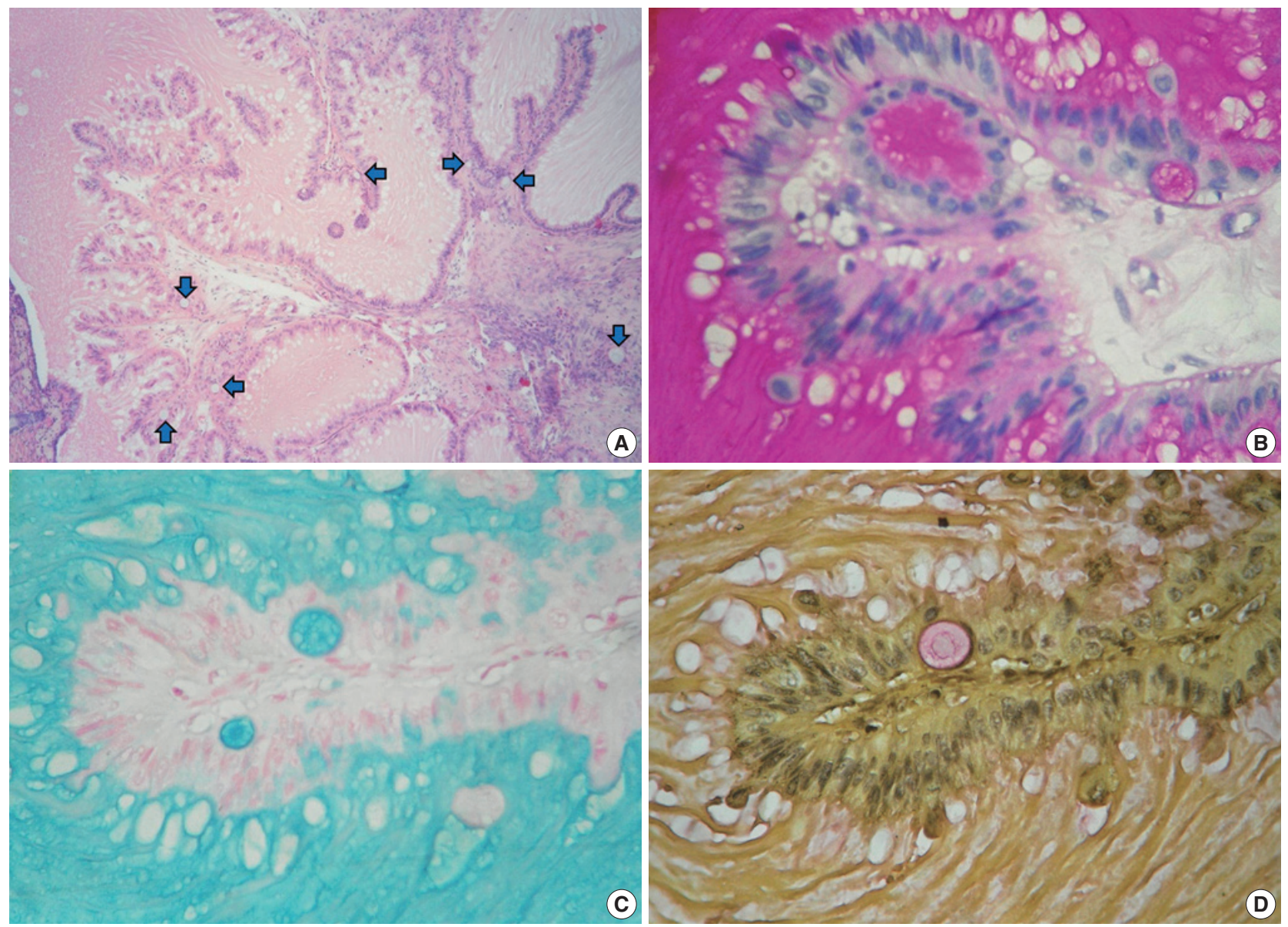

Fig. 2. Mucinous metaplastic components. (A) Some amphophilic mucin-filled cysts are noticeable beneath the epithelium (blue arrows). (B) Periodic acid-Schiff. (C) Alcian blue. (D) Mayer's mucicarmine.

or an adaptive response analogous to Arias-Stella reaction. Interestingly, these characteristics had led Starr et al. ${ }^{2}$ to report in a study two years earlier (1978) about a similar papillary lesion as a primary carcinoma of the Fallopian tube. Even more intriguing is the fact that some authors claimed to observe a single multipolar mitosis in one of the cases reported. ${ }^{3}$ Though ensuing reports failed to provide new insights about the origins of this type of tumor, they accurately detail ultrastructural characteristics of the tumors: luminal border microvilli, sporadic cilia, glycogen particles, "empty" vacuoles, abundant parallel wavy filaments $\sim 6.5 \mathrm{~nm}$ in diameter, numerous mitochondria, and a limited amount of rough endoplasmic reticulum. ${ }^{3,4}$ Reports are also specific about the immunoprofiles: cytokeratin and epithelial membrane antigen positive, and CEA negative- the latter certainly not different from normal tubal epithelium. ${ }^{4}$ Curiously, one paper from 1999 provides evidence for refutation in regard to the inexorable connection of this type of tumor with an immediate postpartum period, demonstrating bilateral partially calcified chorionic villi in addition to the papillary tumor, in a 52-year-old patient. ${ }^{5}$ This particular finding represents unequivocal proof of two previous, dateless ectopic pregnancies, but also brings up questions concerning the timing of the tumor. One particular question is whether the tumor had been quiescent for years or whether it was a newly coincidental discovery. A more recent (2003) communication on the subject compiled the data published during previous years, and stressed the importance of recognizing these tumors as benign and the importance of reporting them as such to clinicians in order to prevent drastic surgical resections among postpartum patients. ${ }^{6}$

As discussed above, a schism prevails concerning the histogenesis of this condition (whether it is reactive or neoplastic), though most authors support the second option (a low-grade borderline tumor). In this regard, the work of D'Adda et al. ${ }^{7}$ is a noteworthy advance in the understanding of this entity, as the study molecularly compares a case of metaplastic papillary tumor with four borderline ovarian tumors and two ovarian ade- 

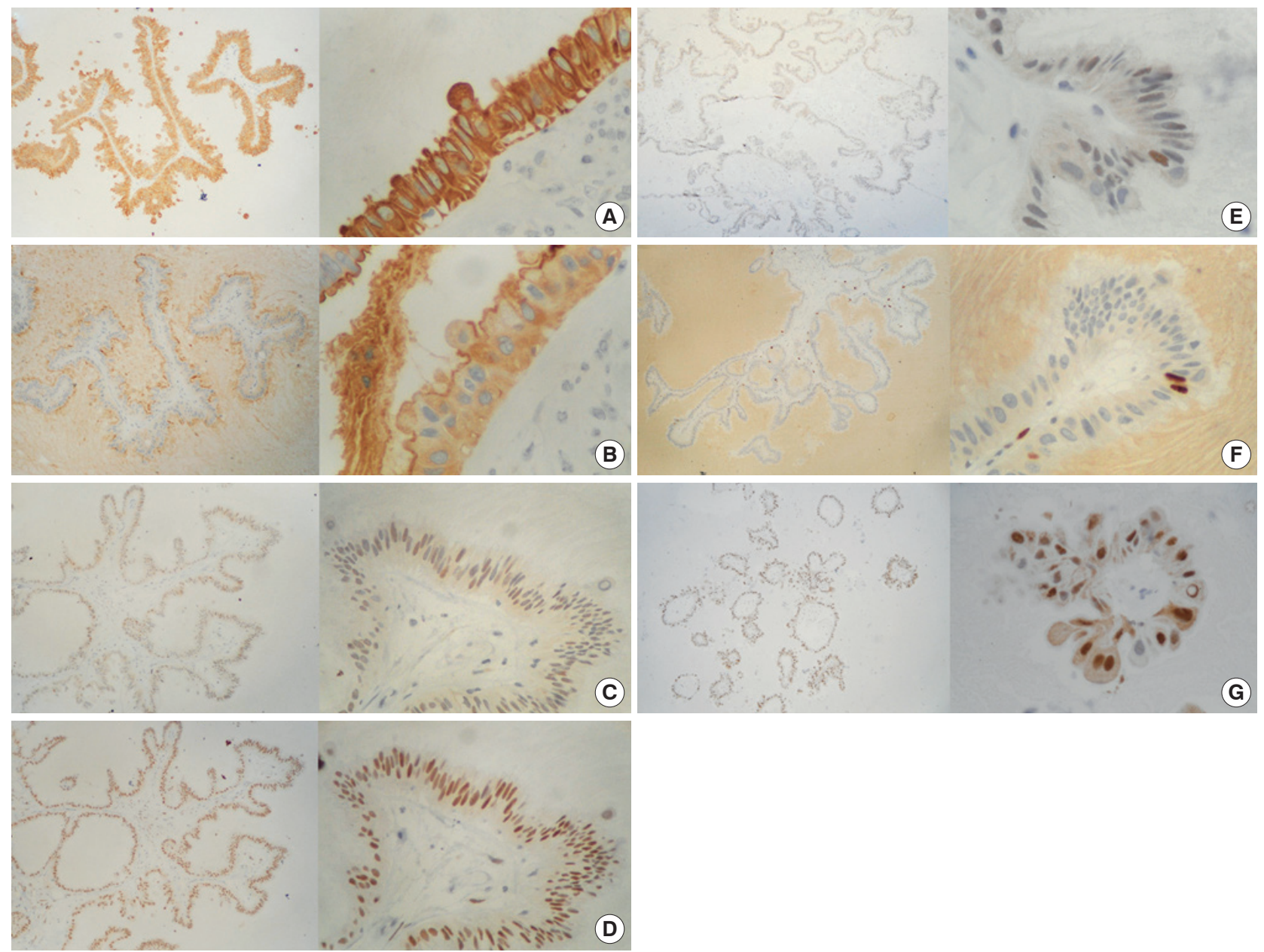

Fig. 3. Immunohistochemistry panel. (A) Cytokeratin $\mathrm{AE}_{1} / \mathrm{AE}_{3}(+++/+++)$ in $100 \%$ of cells. (B) Epithelial membrane antigen (+++/+++) in $100 \%$ of cells. (C) Estrogen receptor (++/+++) in $\sim 70 \%$ of cells. (D) Progesterone receptor $(+++/+++)$ in $\sim 95 \%$ of cells. (E) Androgen receptor (+/+++) in $\sim 10 \%$ of cells. (F) Ki-67 (+++/+++) in $\sim 3 \%$ of cells. (G) Cyclin-D1 (+++/+++) in $\sim 90 \%$ of cells.

nocarcinomas using microsatellite markers directed toward chromosomal regions involved in ovarian carcinogenesis (myc-11, cdkn2a/cdkn2b, pten, tp53, and dmd). According to their findings, the metaplastic papillary tumor, together with one of the borderline tumors, showed no alterations. Thus the study concluded that the metaplastic papillary tumor might share morphologic and molecular similarities with a subset of minimally altered borderline/atypical proliferative tumors.

On the other hand, there are numerous tubal epithelium reactive changes described under different circumstances: cyclic variations in the height and proportion of cells, hyperplasia (mild stratification and papillary tufts), adenomatous hyperplasia (small glandular intramucosal clefts), and metaplasia (squamous, transitional, oncocytic and mucinous). All of these have been known to be associated with inflammation (acute and chronic salpingitis), neoplastic conditions (endometrial carcinoma), hormonal effects (estrogen secreting ovarian tumors or exogenous administration), or even with no particular etiology. ${ }^{1-4,6,8}$ Similarly, as some scholars have proposed, we are quite possibly facing a nonconventional phenomenon analogous to the so-called Arias-Stella reaction in the sense that the tumor might represent some kind of transformation that takes place under similar physiological conditions $^{1,3}$ (as a consequence of antagonistic stimuli acting synchronously—namely, estrogen (ciliogenic and proliferative activity) and progesterone (secretory activity) — either in equal proportion or with an inclination toward one of the stimuli). A seminal review written by Arias-Stella ${ }^{9}$ calls attention to a phenomenon known as transdifferentiation, ${ }^{10}$ which implies the transformation of a mature somatic cell into a different somatic cell preserving its maturity (as opposed to metaplasia, which involves the reprogramming of stem cells). Furthermore, a more dramatic and perplexing process called atypical transdifferentia- 
tion, involving polyploidy, lack of aneuploidy, and the absence of progression as signature traits, ${ }^{9}$ denotes a singular adaptive cellular change said to be found in tissues strained under opposing hormonal influences, consecutively inducing an increment in the content of DNA. The exhaustive analysis throughout this report caused Arias-Stella to conclude definitively that the reaction which has come to carry his name stands for a distinctive example of atypical transdifferentiation, which can be extrapolated to the atypical cells in seminal vesicles, epididymis and duct deferens, the monstrous cells in large solitary luteinized follicle cysts of pregnancy and puerperium, and to the bizarre benign cells in dyshormonogenetic goiter. ${ }^{9}$ Accordingly, we reference the immunoprofile reported for an endometrial Arias-Stella reaction, involving intense and homogenous reactions for $\mathrm{CK} 7$ and EMA with increased membranous locations in hypersecretory patterns, positivity for ER and PR, with a higher estrogen weighting (though weaker in comparison to the normal functional phase and hyperplasia) and positive reactions for Ki-67 and proliferating cell nuclear antigen (though less than hyperplasia or the proliferative phase); as well as the reported ultrastructural characteristics: few organelles, sparse particles resembling RNA granules, clearly visible Golgi apparatus, vesicles of endoplasmic reticulum, numerous mitochondrial crests, Palade grains—ribosomes—and, without exception, parallel rows of rough endoplasmic reticulum, which is a trait said to be common among neoplasms of Müllerian origin. ${ }^{9}$

In the present work, we tried to test the expression of steroid hormone receptors in the oncocytic epithelium in order to confirm the feasibility of hormonal long-acting effects. According to our results, variegation in hormone receptor expression shows the following gradient: progesterone $>$ estrogen $>$ androgen. This ranking suggests a higher progesterone dosing, which corresponds with the secretory effect observed. What is more, we appraised a very low Ki-67 proliferation index ( 3\%), which is consistent with the non-observation of mitotic activity. Nevertheless, it should be mentioned that tubal epithelium normally expresses ER and PR as well as shows a Ki-67 labeling index lower than $5 \%$. The secretory cells of tubal epithelium are typically also positive for the markers HMFG2 and PAX8, while Wilms' tumor gene product (WT-1) is frequently and diffusely expressed in normal Fallopian epithelium. ${ }^{8,11}$ Because at some point in our analysis we presumed a similarity of some of the oncocytic cells with the so-called columnar cell change with atypia or flat epithelial atypia of the breast, we tried to test additional markers such as cyclin D1 and Bcl-2.12,13 To our great surprise, nuclear immunostaining of the former marker was in- deed observed. As a cell cycle marker that interacts with CDK4, CDK6 and tumor suppressor protein RB, we expect to recognize overexpression ( 90\%) of cyclin D1 in correspondence with both mitotic activity and the Ki-67 proliferation index. This, however, is not the case. We believe our observation of this phenomenon in this particular case is similar to the high frequency of cyclin D1 expression seen in either parathyroid adenomas or hyperplastic parathyroid glands. ${ }^{14}$

The differential diagnoses to consider are Fallopian tube papilloma, papillary tubal hyperplasia, serous borderline tumor of the Fallopian tube, and extension from a borderline ovarian tumor. Fallopian tube papilloma is a complex papillary proliferation with an orderly degree of branching that resembles an exaggeration of normal tubal mucosa. ${ }^{8}$ In contrast to a metaplastic papillary tumor, Fallopian tube papilloma maintains normal endosalpingeal cell types. Papillary tubal hyperplasia is a recently recognized entity, which is characterized by papillary tufting and detached small round clusters of bland epithelium that are frequently—but not always — associated with psammona bodies. ${ }^{15}$ Despite focal stratification of the epithelium can be seen, there is usually a single layer containing ciliated and secretory cells as well as intraepithelial lymphocytes. Occasionally, however, there can be slightly larger cells with eosinophilic cytoplasm. Serous borderline tumors of the Fallopian tube are exceedingly rare lesions with a complex papillary configuration lined by ciliated, hobnail and mesothelium-like cells displaying stratification, budding, and focal nuclear atypia. Occasionally, cells with abundant eosinophilic cytoplasm may also be present in serous borderline tumors of the Fallopian tube. ${ }^{8,16,17}$ Mitotic activity is not common. Finally, extension from an adjacent ovarian serous borderline tumor seems to be a reasonable option, which is difficult to rule out, and far more common than either a metaplastic papillary tumor or a tubal borderline malignancy. ${ }^{8,16}$ Undeniably, our patient fits in the age group reported for this lesion, and intriguingly, a minority of affected women are pregnant at the time of diagnosis. The surgeon in the present case, however, did not report any external ovarian anomalies during the course of the bilateral Kroener fimbriectomy. Nevertheless, this statement remains debatable as exophytic papillae are seen in the outer surface of nearly $70 \%$ of ovarian serous borderline tumors. We did not perform immunoperoxidase staining of WT-1, because, as endosalpingeal mucosa and ovarian surface epithelium normally express this marker, ${ }^{8,11}$ the marker loses its diagnostic utility to differentiate a Fallopian serous borderline tumor from its ovarian counterpart. Though some authors claim that metaplastic papillary tumors are microscopic 
findings, $7,8,16$ a couple of reports challenge this assumption by demonstrating that subtle macroscopic changes can be observed. By way of example, a study by Bartnik et al. ${ }^{4}$ describes exudation of pale-yellow mucoid material from an affected tube, while Saffos et al. ${ }^{1}$ illustrate a whole-mount transverse Fallopian section with a conspicuous papillary projection, which, if had been carefully examined, would surely have been grossly apparent as a tumor.

Carrying a good prognosis, Fallopian metaplastic papillary tumors are truly exceptional and remarkable findings in light of their appearance in tubal ligation products and direct relationship to pregnancy. The baroque morphology of a metaplastic papillary tumor challenges up-to-date histopathological taxonomy, and unfortunately, neither electron microscopy, immunohistochemistry, nor molecular biology have completely unveiled the roots of the condition. As interestingly quoted by Keeney and Thrasher in their report ${ }^{3}$ "... despite [the fact that] light microscopy does not reveal an actual differentiation to another cell type, examination through electron microscopy strongly suggests a metaplastic process at an ultrastructural level with an incomplete transition towards a recognizable cell phenotype...." This statement undoubtedly leads us to inquire whether this metaplastic tumor could be an overly exaggerated example of atypical transdifferentiation, drawn forth by hormonal influences in an appropriate physiological environment. Indeed, we believe this could be the case.

Lastly, as neoplastic changes have not been entirely demonstrated in the condition of metaplastic papillary tumors, we suggest not referring to the alterations as either tumors or lesions (specifically because the condition has been proved to be harmless). Perhaps designation as a Fallopian metaplastic papillary polyp - implying a convex branching axis towards a lumen—is more suitable nomenclature for the characteristics we describe herein.

In summary, we report the 11th known case of a patient with a metaplastic papillary tumor of the Fallopian tube, and provide brief insight about the topic.

\section{Conflicts of Interest}

No potential conflict of interest relevant to this article was reported.

\section{REFERENCES}

1. Saffos RO, Rhatigan RM, Scully RE. Metaplastic papillary tumor of the Fallopian tube: a distinctive lesion of pregnancy. Am J Clin Pathol 1980; 74: 232-6.
2. Starr AJ, Ruffolo EH, Shenoy BV, Marston BR. Primary carcinoma of the Fallopian tube: a surprise finding in a postpartum tubal ligation. Am J Obstet Gynecol 1978; 132: 344-5.

3. Keeney GL, Thrasher TV. Metaplastic papillary tumor of the Fallopian tube: a case report with ultrastructure. Int J Gynecol Pathol 1988; 7: 86-92.

4. Bartnik J, Powell WS, Moriber-Katz S, Amenta PS. Metaplastic papillary tumor of the Fallopian tube. Case report, immunohistochemical features, and review of the literature. Arch Pathol Lab Med 1989; 113: 545-7.

5. Pang LC. Hydrosalpinx due to asymptomatic bilateral tubal pregnancies associated with metaplastic papillary tumor of the Fallopian tube. South Med J 1999; 92: 725-7.

6. Solomon AC, Chen PJ, LiVolsi VA. Pathologic quiz case: an incidental finding in the Fallopian tube. Fallopian tube, left, tubal ligation: metaplastic papillary tumor of Fallopian tube. Arch Pathol Lab Med 2003; 127: e363-4.

7. D'Adda T, Pizzi S, Bottarelli L, Azzoni C, Manni S, Giordano G. Metaplastic papillary tumor of the salpinx: report of a case using microsatellite analysis. Int J Gynecol Pathol 2011; 30: 532-5.

8. Vang R, Wheeler JE. Diseases of the Fallopian tube and paratubal region. In: Kurman RJ, Ellenson LH, Ronnett BM, eds. Blaustein's pathology of the female genital tract. 6th ed. New York: Springer, 2011; 529-78

9. Arias-Stella J. The Arias-Stella reaction: facts and fancies four decades after. Adv Anat Pathol 2002; 9: 12-23.

10. Selman K, Kafatos FC. Transdifferentiation in the labial gland of silk moths: is DNA required for cellular metamorphosis? Cell Differ 1974; 3: 81-94.

11. Rabban JT, Soslow RA, Zaloudek CZ. Immunohistology of the female genital tract. In: Dabbs DJ, ed. Diagnostic immunohistochemistry: theranostic and genomic applications. 3rd ed. Philadelphia: Saunders Elsevier, 2010; 690-762.

12. Kurman RJ, Vang R, Junge J, Hannibal CG, Kjaer SK, Shih IM. Papillary tubal hyperplasia: the putative precursor of ovarian atypical proliferative (borderline) serous tumors, noninvasive implants, and endosalpingiosis. Am J Surg Pathol 2011; 35: 1605-14.

13. Alvarado-Cabrero I. Pathology of the Fallopian tube and broad ligament. In: Nucci MR, Oliva E, eds. Gynecologic pathology: foundations in diagnostic pathology. Philadelphia: Churchill Linvingstone, 2009; 331-66.

14. Krasevic M, Stankovic T, Petrovic O, Smiljan-Severinski N. Serous borderline tumor of the Fallopian tube presented as hematosalpinx: a case report. BMC Cancer 2005; 5: 129.

15. Feeley L, Quinn CM. Columnar cell lesions of the breast. Histopathology 2008; 52: 11-9. 
16. Walker RA, Hanby A, Pinder SE, Thomas J, Ellis IO; National Coordinating Committee for Breast Pathology Research Subgroup. Current issues in diagnostic breast pathology. J Clin Pathol 2012; 65: 77185.
17. DeLellis RA, Shin SJ, Treaba DO. Immunohistology of endocrine tumors. In: Dabbs DJ, ed. Diagnostic Immunohistochemistry. Theranostic and Genomic Applications. 3rd ed. Philadelphia: Saunders Elsevier, 2010; 291-339. 